\title{
UNDERSTANDING THE CAUSES OF THE DEBT-CRISIS: INTEREST-BASED FINANCING
}

\author{
Abdul Karim Abdullah (Leslie Terebessy)*
}

\begin{abstract}
This article looks at ribā-based financing from the perspective of efficiency, within the context of Islam. In particular, it tries to address the question whether interest-based financing results in a more efficient allocation of resources, as claimed by its supporters, than financing on the basis of profit and loss sharing, as claimed by the supporters of Islamic finance. ${ }^{1}$ Efficiency is used in this article primarily in its macroeconomic sense, in which it signifies the production of goods and services that meet the needs of the people, without generating persistent surpluses or shortages. ${ }^{2}$
\end{abstract}

\section{Introduction}

A number of observers, including Muslims, have expressed the view that Islamic finance results in a less efficient allocation of resources than its conventional counterpart, interest-based finance. This claim is commonly made in the context of the rationing of capital theory of interest rates, and also by asserting that raising capital in the form of equity is more expensive (due to higher listing costs, commissions, legal fees, etc.) than financing using loan capital. Both claims are problematic. If it can be shown that financing on the basis of profit and loss sharing results in a more efficient allocation of resources than financing on the basis of lending at interest, then the case for the phasing out of financing using interest-based loans and its replacement by financing on the basis of profit and loss sharing can be strengthened on rational grounds, in addition to following the divine (qur'ānic) ruling on this issue. Due to constraints of space, the focus is on riba-based financing, with only passing references to profit and loss sharing.

Many of the weaknesses of the conventional system of finance stem from the diversion of capital from the real economy into wasteful uses in the financial sector, for example, for the purpose of speculative trading of debt or receivables. ${ }^{3}$ As a result, every economic system that utilises interest-based financing has been performing well below capacity, to the extent that it relies on such financing. Persistent inflation and unemployment constitute the clearest evidence of this lacklustre performance, even in developed countries. Indeed, the view expressed in this paper is that both inflation and unemployment - each a different manifestation of macroeconomic inefficiency - are directly attributable to interest-based financing.

* Abdul Karim Abdullah (Leslie Terebessy) is Assistant Research Fellow at IAIS Malaysia. 
Ribā-based financing causes other problems. It diverts resources from the real sector into the largely unproductive financial sector. As funds flow to finance the trading activities of bond traders, less capital remains available to fund the real economy. ${ }^{4}$ As a result, real investment declines. Economic growth slows down and unemployment rises. Both signify a reduction in the efficiency with which resources are allocated.

Strange as it may seem, the trading of debt (bonds) is said to make the financial markets more efficient. But an efficient allocation of resources requires more than ensuring that securities with comparable risk and return profiles trade at nearly identical prices in different markets. Efficiency - in particular macroeconomic efficiency - requires the production of goods and services that people need, in the quantities in which they need them, and at prices at which they can afford them. This type of efficiency is best realised when financing takes place on the basis of profit and loss sharing, rather than on the basis of lending at interest. ${ }^{5}$ As one observer noted, "The economic strength of a PLS system lies in [...] diverting energy normally expended on non-productive speculation into productive activity." 6

However, sceptics view the claims that profit and loss sharing would bring higher returns to investors, a more efficient allocation of resources, higher economic growth, and an enhancement of individual and social welfare as "vacuous." Attempts to establish Islamic alternatives to the current $r i b \bar{a}$-based monetary system they insist "must be seen as pipe dreams." Any such attempts, in the view of these observers, will "almost certainly turn out to be a wild goose chase." "Observations of this nature, however, only confirm the adage about the person who "sees the speck in his brother's eye and overlooks the log in his own." ${ }^{\prime 10}$ While such critics are quite prepared to highlight what they think of as weaknesses in Islamic finance, they remain oblivious to far greater problems in conventional, interest-based finance.

Other commentators see few differences between profit earned from trade and interest: "From an economic point of view, there is indeed no substantial difference between mark-up and interest." 11 This reminds one of the claim - critiqued in the Qur'ān - that 'trade is like ribāa.' Some go so far as to assert that "there is no such thing as finance without interest." 12 Additional grievances include the assertion that Islamic finance is hampered by too many "restrictions." 13 These restrictions "increase the cost" of financing, and thus make it less efficient. ${ }^{14}$ The corollary of these claims is that conventional financing, compared to Islamic financing, is efficient, indeed more efficient than financing on a profit and loss sharing basis (Islamic financing). ${ }^{15}$

Yet the facts speak otherwise. Perhaps the clearest proof of the inefficiency of interest-based financing is provided by the simple fact that lenders collect interest payments without making any palpable contribution to the production process. ${ }^{16}$ In other words, interest income is earned without providing any counter value - products or services - in return. ${ }^{17}$ This can only happen when capital is viewed as a factor of production. But it is doubtful whether capital in itself is a factor of production. 
Capital alone does not produce anything: an automobile by itself cannot provide any service: it needs a driver to make it productive. A weight of gold locked away in a safe will not grow over time. It takes an entrepreneur to earn profit. Productivity arises only when capital is put to use. To view capital as a factor of production is, accordingly, hardly an intellectually if not also a morally defensible position, as it is quite clear that capital by itself cannot produce anything. Payments of interest to the lender come from the income generated by the labour of others.

At the same time, unemployment has been hovering at rates comparable to the prevailing rates of interest. In a mature economy, such as the US, the share of interest income out of total national income ranges from $5 \%$ to $10 \%{ }^{18}$ This proportion provides a measure of the waste (or macroeconomic) inefficiency of interest-based financing, as it gives an indication of how much is paid to lenders. ${ }^{19}$

As interest paid to lenders constitutes essentially unearned income, if the same proportion of national income (5\% to $10 \%)$ were paid to the unemployed in exchange for productive activity, the problem of persistent unemployment - as well as the idleness of lenders - would in principle be solved. This would require phasing out interest-based financing and replacing it with financing on the basis of profit and loss sharing. Nevertheless, one can expect resistance to an economic transformation of this magnitude, in particular from parties that would stand to lose most from such a change, the shareholders of $r i b \bar{a}$-earning financial institutions in particular. ${ }^{20}$ The challenge of implementing ribā-free financing, in other words, remains as much political as it is economic.

In response to the other objections against Islamic financing, it is necessary to reiterate that Islam is not against trade or even capitalism, if capitalism means the use of capital for the purpose of earning a profit by providing needed goods and services. On the contrary, Islam supports trade - as long as it is trade in approved goods and services - including free trade. This is evident from the verse "Allah has permitted trade $[\ldots] .{ }^{, 21}$

Moreover, contrary to the claims of its critics, Islamic finance is subject to very few restrictions. This is clear from the principle of permissibility (ibahhah) in commercial transactions, which means that unless a practice is explicitly forbidden by a clear text, then it is permitted. ${ }^{22}$ In general, Islam requires all income to be earned in an honest, acceptable manner, through labour and enterprise.

To gloss over the differences between profit and interest is unwise, as profit and interest constitute very different incentives for driving economic activity. These differences have profound implications for the efficiency with which resources are will be allocated. ${ }^{23}$ Finally, to claim that there is no financing except financing by way of interest-yielding securities is to ignore the existence of in excess of $\$ 40$ trillion equities outstanding globally. 
The charging of interest on loans has become so entrenched in mainstream thinking that the unfavourable effects of interest-based lending are rarely noticed, much less questioned. ${ }^{24}$ On the contrary, its supporters attribute many benefits to interest-based lending. Upon closer examination, however, these attributes prove to be tenuous at best and counterproductive if not downright harmful at worst.

Riba $\bar{a}$-based financing, far from enabling a more efficient allocation of resources has, on the whole, had precisely the reverse effects. ${ }^{25}$ The most damaging effects of riba $\bar{a}$-based financing show up in the form of inflation, unemployment, and reduced or negative economic growth. The inefficiencies evidenced by all three leading economic indicators are directly attributable to interest-based financing. Thus, far from facilitating economic development and growth, as is commonly claimed by its supporters, riba $\bar{a}$-based financing has on the contrary hindered it, and effectively caused any system that utilises it to function at below optimal (full employment) capacity.

Despite its many weaknesses, $r i b \bar{a}$-based financing enjoys considerable support among economists. One view expressed in its support is that the ability to earn interest $(r i b \bar{a})$ encourages people to save, thus providing a pool of capital available for investment. The view that interest rates constitute an indispensable incentive to save, however, is supported neither by reason nor evidence. Keynes, among others, has shown that saving is a function of disposable income as much, if not more, as of incentives offered to savers in the form of interest which, in any case, in most instances are quite minimal. ${ }^{26}$

A more effective incentive to save is provided by opportunities to invest for profit, for example in real estate, than by the earning of interest, as profits from investments in real property generally outperform earnings of interest income. Investment in shares (equity) provides another alternative form of savings that directly supports the real economy. The quantum of dividends, unlike payments of interest, is not limited (capped) by being pre-determined. Investors accordingly have the prospect of earning profits potentially significantly higher than those guaranteed to them in the form of interest earnings, which are minimal on most savings deposits by comparison to profits earned by well managed companies. ${ }^{27}$ It is widely acknowledged that investments in common shares outperform returns on interest yielding sources of income by a margin of $5 \%$ to $6 \%$. The view that without the rewards offered to savers in the form of interest little or no saving would take place is therefore unconvincing.

Financing on a profit and loss (PLS) basis (equity financing) is a major form of financing in the conventional sector, and the only acceptable form of financing in the Islamic sector. ${ }^{28}$ Equity or equity-like (Islamic) financing is the backbone of the real economy. Financing on the basis of profit and loss sharing is particularly "conducive to increased efficiency because of the personal stake and interest of the entrepreneur in his own business. ${ }^{29}$ It is the link between effort (performance) and 
reward (profit/loss) in financing on the basis of profit and loss sharing that ensures more than anything else that resources will be allocated efficiently. Where this link is absent or impaired in some way, and the incentives in the form of profits and losses for allocating resources are lacking, resources are unlikely to be allocated to their most profitable (efficient) uses.

\section{Effects of Ribā-Based Financing: High Debts}

Much financing of investment, both public and private, has been financed by interest-based debt. One of the most glaring effects of interest-based financing is the accumulation of growing amount of debt. This debt is in some cases so large that it may appear all but impossible to repay. ${ }^{30}$ The magnitude of debt has been increasing not only due to additional borrowing, but also due to interest charges, including compound interest (interest on interest) charges.

At some point all debt has to be paid back. The need to repay debt will necessitate a reduction in spending during the time of repayment. When spending is reduced to repay debt, economic growth will slow down, further reducing the ability of a debtor nation to repay debt. ${ }^{31}$

It has become increasingly clear, however, that financing growth by interestbased debt is not sustainable in the longer term. The existence of large and growing debts poses a threat not only to the financial stability of households, businesses and governments, but also to the systemic stability of the financial system as a whole.

A major adverse effect of interest-based financing is a waste (inefficient allocation) of resources. ${ }^{32}$ A glaring example of such inefficiency - indeed waste of resources on a massive scale - directly attributable to riba $\bar{a}$-based financing, is provided by the large surplus of abandoned homes in the United States, financed by ribā-based subprime mortgages.

These mortgages were bundled together and sold on to institutional investors such as pensions funds in the form of collateralised debt obligations or CDOs. The perception that these debts (or debt obligations) were collateralised, in other words perceived as secured or safe investments, was reinforced by the fact that rating agencies assigned triple A ratings to these CDOs.

The perception that these were safe investments created a massive moral hazard on the part of the investors, as it relieved them - or so they may have thought of the need to perform due diligence and check the commercial viability of their investments. In other words, the perception that their interest income was guaranteed, or the perception that there was little or no risk in these investments, was a major factor leading to the massive overinvestment or a misallocation (waste) of resources.

Thus, it was the perceived absence of risk - of not having to share risk - that directly facilitated this instance of massive misallocation of resources. Had the 
investors been required to share risk with the entrepreneurs, the chances of this taking place would have been far lower. In this way, profit and loss sharing financing would have reduced, if not effectively eliminated such a massive misallocation (inefficient) use of resources.

Risk taking serves a very important function in the efficient allocation of resources. It restrains investors from making excessively risky (gharar) investments. Where this risk does not exist, or is perceived not to exist, the restraining effects of risk taking will have little effect. Thus, secured lending fosters what one could term as a financially high-risk lifestyle characterised by recklessness and fiscal irresponsibility. Secured (risk-free) investment creates a false sense of security for investors, who may subsequently be in for a rude awakening, when they find out that the risk was there all along, only that they did not perceive it.

Something clearly went wrong in a system that financed such a surplus of homes that eventually no one would occupy. ${ }^{33}$ Many of these houses are now being torn down owing to dilapidation. When the market correction came in the form of a dramatic increase in interest rates, a large number of persons were unable to continue to pay their loans and as a consequence lost their homes. Others became unemployed in various sectors, including in the financial sector. Much hardship was caused for countless families.

Adjustable rate subprime mortgages that were used to finance the construction of these homes exposed borrowers to excessive risk (gharar) in the form of interest risk. When interest rates began to rise dramatically in 2005, many homebuyers with adjustable rate mortgages could not afford the higher monthly payments demanded by the financial institutions and defaulted. ${ }^{34}$ Because the houses purchased served as collateral for the mortgages, the homes of the defaulters were subsequently repossessed by the financial institutions, leaving countless families homeless.

A similar example of an inefficient commitment of resources on a massive scale is evidenced by the surplus of commercial and residential properties in Dubai, similarly financed by rib $\bar{a}$-based loans or loan equivalents. Loans were extended on the basis of the strong collateral provided by the oil revenues of the United Arab Emirates, the proven reserves of oil not yet extracted, as well as the United Arab Emirates sovereign wealth fund, conservatively estimated to exceed US\$600 billion. One may well wonder why, with sovereign wealth funds of this magnitude, there would be any need to borrow funds in the first place. ${ }^{35}$ The collateral-centred lending and the resulting overinvestment resulted in a massive misallocation of resources, in other words, inefficiency or waste on a large scale.

Automobile companies in the United States have been saddled with massive debts, necessitating publicly funded bailouts. This has been taking place in a number of industrialised countries that financed much of their growth by debt, such as Japan, the United States, and a number of European Union nations. But the need to repay 
debt, together with compound interest, effectively throttles economic growth in the longer term by reducing the volume of spending required to maintain robust levels of production.

Additional inefficiency of riba-based financing is caused by the fact that such financing discourages innovation, as companies will hesitate to experiment with risky methods of production, which may cause losses and make it harder to repay loans. ${ }^{36}$

Interest-based financing has likewise produced large debts in the public sector, in the form of the national debt. A large and growing national debt necessitates the allocation of progressively larger amounts of tax revenue for the purpose of servicing and repaying the debt. This imposes a significant burden on taxpayers, especially on future generations. It reduces their disposable income, both present and future. As a result, their ability to spend will be curtailed, causing a reduction in aggregate demand and a slowdown of economic growth.

In the public sector, the more governments borrow, the more they have to pay back, and the higher the service (interest) charges on the debt. A growing proportion of tax revenues need to be diverted from other uses to service large, and sometimes growing, debts. This means that there will be less and less public revenue left to provide social services such as healthcare and education, and to pay the salaries of government employees. Government employee lay-offs, austerity measures and belttightening can all be expected to follow sooner or later. ${ }^{37}$ Lay-offs and retrenchments can be expected to rise. A rise in unemployment will signal a reduction of efficiency in the use of human resources. This is one way in which the need to pay interest to lenders on public debt adds to unemployment and thereby reduces the efficiency in the use of (human) resources.

Moreover, all working citizens and residents pay taxes, but only a few are in a position to buy government bonds (to lend money to the government). For this reason, public sector borrowing and the need to service public debt have the additional effect of channelling substantial sums of money on an on-going basis from ordinary people to the wealthy. This has exacerbated, and continues to widen, the gap between the wealthy and the poor.

\section{Efficiency and Competition}

Efficiency, which can be defined as productivity, is a central concept in economics and finance. Efficiency is the opposite of waste $\left(\right.$ diya $\left.a^{c}\right)$. Efficiency is realised when waste is minimised. Different forms of waste represent different types of failure to realise one's potential, whether on a social or personal level. Realisation of efficiency thus requires full utilisation of resources. Waste is censured in the Qur'ān as reprehensible (makrūh) or unethical. ${ }^{38}$ Efficiency is a positive trait from the perspective of Islam, as it implies the absence or opposite of waste. "But waste not by excess, for Allah loveth 
not the wasters." "39 "But squander not (your wealth) in the manner of a spendthrift."40 Squandering (isrāf) is also condemned..$^{41}$

Efficiency has two primary forms: macroeconomic and microeconomic efficiency. Macroeconomic efficiency in the use of resources is achieved when those products and services are supplied that people need, produced in the quantities in which they need them, and sold at prices at which they can afford them. ${ }^{42}$ Prolonged shortages or surpluses in any area, or artificially high prices, constitute evidence of inefficiency. Shortages indicate that too few resources are allocated to providing a given product or service; surpluses signify the reverse.

Macroeconomic indicators of efficiency comprise the unemployment level, the rate of economic growth (GDP) and the rate of inflation. A low rate of unemployment, stable prices, and a high rate of growth all indicate higher (macroeconomic) efficiency, other factors being constant. Unemployment, inflation, and negative growth all indicate inefficiency in the overall allocation of resources.

Fluctuations in the movements of the leading economic indicators indicate changes in the levels of efficiency with which resources are allocated. Periods of growth reduce unemployment and thereby increase the efficiency of resources allocation. Thus a rise in GDP (with a corresponding drop in the unemployment rate) signifies an increase in efficiency. An increase in inflation, by contrast, indicates a reduction of efficiency. ${ }^{43}$

Microeconomic efficiency takes place at the level of the individual firm or business. Since any firm earns higher profits by utilising its resources more efficiently, other factors remaining constant, the attainment of efficiency is a major objective of the firm. One measure of microeconomic efficiency is cost per unit. Efficiency is maximised when the costs per unit are minimised, without compromising quality of the product or service provided.

Another measure of efficiency is productivity: the number of products (output) generated by a given resource (input) over a specific period of time. Productivity is related to cost per unit. Higher productivity reduces cost per unit. Increasing productivity or reducing cost per unit thus signals a gain in efficiency. A fall in the price of a product, made possible by lower costs of production, other factors (such as quality) remaining constant, likewise signals an increase in efficiency. Another measure of microeconomic efficiency - assuming that the industry in which the firm operates is competitive - is profitability. Higher profitability in competitive industries can be achieved by increasing productivity or reducing cost per unit.

Macroeconomic and microeconomic forms of efficiency are related. A reduction or elimination of waste, other factors remaining constant, increases productivity (output) and therefore also efficiency. A more productive (efficient) business, that is, a business able to produce at a lower cost per unit, becomes more profitable. As businesses become more profitable, they are able to pay higher wages, taxes, 
and dividends, as well as to contribute more to charitable causes. Higher efficiency translates into rising profits for shareholders as well as a higher national income, a measure of national output. Higher overall output increases economic growth, and reduces unemployment and inflation, all at the same time. This increases efficiency in the macroeconomic sense.

People's needs are met by the production and delivery of goods and services. Some are provided by the public sector, others by the private sector. Prices - more precisely price changes - help to allocate resources efficiently. ${ }^{44}$ In a competitive environment, the price of a given product or service is an indication of the value that society collectively places on a given product or service. Rising prices, other factors remaining constant, signal rising demand for a given product, resource, or service. They also signal rising short-term profitability for businesses willing to supply more of a product or service in demand. This will attract additional resources into the production of goods and services. Falling prices, by contrast, signal declining profitability and therefore have the reverse effects. They free resources for alternative (more profitable) uses elsewhere. As prices and profitability change, reflecting changes in social priorities, resources are reallocated from less profitable (efficient) uses to more profitable ones, thereby better fulfilling the society's needs for various goods and services.

In the absence of market or regulatory failure, markets are generally efficient. Market failure takes place when firms eliminate competition among themselves by colluding to fix and thereby raise prices in order to increase the profits of their shareholders at the expense of consumers. Regulatory failure takes place when authorities fail to prevent or put a stop to collusion and other practices that limit or eliminate competition among firms, thereby increasing prices and their profits at the expense of consumers. Competition is a necessary condition for the efficient allocation or resources.

Regulatory failure also takes place when authorities put in place a structural (legal) framework or system that privileges the few at the expense of the many. Such practices limit competition by means of exclusive (import, manufacturing or service) licenses and monopolies. Such practices cannot but have profoundly adverse effects on the efficiency with which resources will be allocated, and thereby on the prosperity and the even distribution of wealth in the community as a whole. The fortunes of a few may rise, without the need to compete on their part, but the prosperity of the community as a whole is bound to languish.

Nevertheless, structural intervention in the form of affirmative action policies that seek to rectify past injustice and restore balance between communities and a level playing field do not constitute regulatory failure but rather regulatory intervention, justified by considerations of public interest (mașlahah), in cases where markets alone cannot be relied upon to provide the required corrections. 
Profitability serves as a meaningful measure of efficiency only in competitive industries. These do not need to be perfectly but at least substantially competitive. ${ }^{45}$ High profitability of a monopoly or an oligopoly does not indicate a high degree of efficiency. Quite the contrary, monopolies and oligopolies are highly inefficient and profitable at the same time. This is caused by the absence of competition or the presence of limited competition. ${ }^{46}$ Monopolies and oligopolies raise profits by restricting entry for others (potential competitors) to their industries. Preventing others from entering selected industries, however, runs counter to the qur'ānic injunction permitting trade, and of several qur'ānic verses and hadìths that proscribe hoarding and profiteering. ${ }^{47}$

\section{Ribā and Efficiency}

Productive activity is driven by a system of incentives, Adam Smith's invisible hand. These incentives take the form of various rewards earned by those who participate in productive activity. Under competitive market conditions - and in the absence of other types of market failure - the magnitude of reward paid to a factor of production in the real sector generally depends on the productivity (efficiency) of the factor. Higher productivity is rewarded with higher pay, while lower productivity earns a lesser reward. Parties that provide capital by lending at interest, however, constitute an exception to this rule, because the rewards paid to creditors are not linked to the productivity of the assets they finance. ${ }^{48}$ Rather, they are linked to the amount of capital they provide.

The link between reward and productivity constitutes a central pillar of the free enterprise economy. It provides a mechanism for individuals and businesses to maximise productivity. Assuming no asymmetry of information and other forms of market failure, all are rewarded in proportion to their effort or contribution. Different factors of production are rewarded in different ways. Reward (incentive) for labour (productivity) comes in the form of wages. Reward for entrepreneurial (risk-taking) activity comes in the form of profit. Tax revenues pay for government services. The incentive for lending, however, takes the form of interest income.

What makes interest payments different from payments of wages or profits is that payments of interest are determined in a different way than payments to the suppliers of labour (who earn wages) or the suppliers of entrepreneurial expertise (who earn profits). Both profit paid to entrepreneurs and wages paid to workers depend, at least in principle, on their respective contributions, whether these are in the form of productivity, ingenuity or some other form.

But the payment of interest to the lender does not depend on any of these factors. The reason why the magnitude of the interest paid to the lender does not - and indeed cannot-depend on the lender's productivity, is that the lender does not participate in the production process. 
Neither can the reward paid to the lender be determined according to the productivity of his capital because capital, as we have seen, in itself is likewise not productive. Finally, the reward paid to the lender does not depend on the profitability of the enterprise he helps to finance either, because the payments of interest are specified in advance. Thus, the amount of interest to be paid to the lender needs to be determined by reference to some other factor.

This other factor invariably turns out to be the amount of capital supplied (loaned) by the lender. The amount of interest owed to the lender is commonly specified as a proportion of the total capital loaned, to be paid every year or at other agreed upon intervals. The proportion of the total capital loaned to be paid in the form of interest is in turn determined by reference to the prevailing rate of interest, as well as other factors.

Thus, payments of interest to the owners (lenders) of capital are determined independently of the productivity (efficiency) of the enterprise that the lender helps to finance. And herein lies the greatest weakness of interest-based financing. The weakness is the absence of a strong incentive to the providers of capital to maximise efficiency (profitability). Riba (interest) - compared to profit - constitutes a weak incentive for rewarding suppliers of capital for channelling resources to their most profitable (efficient) uses. Unlike payments to factors of production, payments of interest to creditors are not linked to the efficiency (productivity) of the businesses they finance. ${ }^{49}$ Creditors thus in principle have no incentive to take any steps to increase the efficiency of the enterprises they finance.

Unlike profit and loss sharing securities, any change in the efficiency (profitability) of a given businesses does not translate into a change in the interest payments to creditors. Payments of interest to creditors neither rise nor fall with efficiency (profitability). A change in the efficiency of a business financed by credit has no impact on interest payments made to creditors, as long as the change does not result in profits lower than the minimum required to repay loans with interest. Thus, lenders have nothing to gain from an increase in the efficiency (profitability) of the enterprises they finance, as the payments of interest have been determined - fixed - in advance.

Since in most cases their capital is guaranteed, lenders have little incentive to participate in the management of the companies they finance or to exercise any oversight of the company's operations. This cannot but create a moral hazard by reducing the incentive for company management to use the resources entrusted to it wisely and efficiently. Secured lending at interest introduces a moral hazard in that it absolves creditors from any responsibility for the outcome of the investments they finance.

The fact that the interest income paid to creditors bears no direct relationship to the efficiency of the enterprises they finance constitutes a major anomaly in - and 
is indeed inconsistent with a basic principle of - the free enterprise economy. The principle is, - to reiterate - that reward should be linked to and made dependent on effort. Capital providers (lenders) are rewarded (in the form of interest payments) without contributing to production, either in the form of effort or by taking risk. This alone constitutes evidence of inefficiency.

The absence of a meaningful link between the efficiency of the enterprises financed and the rewards to capital providers (creditors) has far-reaching implications for the efficiency with which resources can be allocated in any system that utilises interest-based financing. It is a time-tested truism - confirmed by the experience of communism - that severing the link between performance and reward profoundly reduces, if it does not eliminate outright, the incentive for productivity (efficiency), thereby laying the foundation for economic stagnation and decline. ${ }^{50}$

In order to ensure a more efficient (socially useful) allocation of resources, financing on the basis of interest-based debt needs to be replaced with financing on the basis of profit and loss sharing. ${ }^{51}$ Microfinance - small scale financing on a profit and loss sharing basis - could be given additional support. Muslims need to have confidence in their own principles rather than mimic conventional practices. ${ }^{52}$ Regulatory frameworks need to be amended to eliminate practices (such as treating interest payments as expenses) that favour interest-based financing over financing on the basis of profit and loss sharing. Once these structural changes are accomplished, equity financing is more likely to become the choice method of financing for businesses on account of its more efficient character.

\section{Ribā and Inflation}

In general, a reduction in the cost or price of a resource or a product signals an increase in efficiency, while an increase in the cost of a resource or product signals the reverse. Inflation is a general increase in prices. In so far as rising prices signal the rising cost of goods, services, as well as resources, inflation signals a reduction of efficiency.

Spending financed by borrowing at interest contributes to inflation, and therefore reduces efficiency, in at least two ways. The extra demand for goods and services spending by consumers, businesses, and governments - made possible by spending borrowed money adds to "demand pull" inflation. It is estimated that more than 1 trillion credit cards are in use in the United States alone.

Inflation imposes a variety of costs on society. It increases the costs of doing business, thereby reducing output and contributing to unemployment. It also reduces the purchasing power of currency, thus reducing the real income of the population, especially of those living on fixed incomes such as pensioners. ${ }^{53}$ Inflation also reduces the purchasing power of people's savings. 
Financing business investment by funds borrowed at interest adds to inflation in the form of "cost-push" inflation. Businesses that borrow at interest to finance expansion or investment treat interest payments as expenses. Businesses normally pass their expenses, including interest payments, on to consumers in the form of higher product and service prices. This will cause inflation. Thus, if a business needs to service a business loan at for example $8 \%$ per annum, it can be expected to increase the prices of the goods or services it supplies by a comparable amount, also $8 \%$.

Riba $\bar{a}$-based financing adds to inflation in another way. Payments of interest by borrowers to lenders, as well as by financial institutions to depositors, gradually expand the money supply, even without any intervention by the central bank. On account of these payments alone, the money supply can be expected to grow at a rate at least equal to the average between the lending and savings rates. If the average savings rate on deposits is $2 \%$ per annum and the average lending rate is $8 \%$ per annum, the money supply will grow by $5 \%$ per annum.

The expansion of the money supply due to payments of interest should have little impact on prices as long as the rate of expansion does not exceed annual real GDP growth. However, any expansion of the money supply in excess of real GDP growth will likely cause significant inflation. The extent of inflation, however, will also depend on other factors, such as the velocity of money (V), a variable that is particularly hard to measure and predict. $^{54}$

The link between interest-based financing and inflation may explain why historically interest rates and the rate of inflation tended to be nearly equal to one other, and generally move up and down in tandem. It would appear, accordingly, that replacing financing by way of interest-based loans by financing on the basis of profit and loss sharing could be expected to reduce persistent inflation, if not eliminate it altogether. This would signal, in the form of more stable prices, a dramatic rise in the efficiency in the allocation of resources across the economic spectrum. A significant reduction in inflation would bring many additional benefits. It would protect the purchasing power of the currency, stabilise real income, and lessen the hardships faced by parties on fixed incomes in the form of continually rising prices. Indeed, the principle of raf' al-haraj ("removal of hardship") requires that such hardships be alleviated, especially those facing the low income groups and the hardcore poor. ${ }^{55}$

\section{Ribā and GDP}

Contrary to a popular and widely held belief, rib $\bar{a}$-based financing, apart from stimulating aggregate demand by providing investment funds in the short run, actually impedes growth (GDP) and development in the longer run. This happens as a result of the fact that any funds borrowed to finance investment (or consumption for that matter) have to be repaid - with interest. When loans are repaid, aggregate 
demand is reduced by the amount of repayment, and GDP growth slows down due to a reduction in overall demand. Because repayments are greater, due to interest charges, than the initial spending of money borrowed at interest, the overall effect is one of reducing aggregate demand rather than increasing it over the entire cycle of borrowing, spending, repayment and reduced spending. Thus, the overall effect on economic growth of financing consumption and investment with funds borrowed at interest over the course of the entire business cycle is negative rather than positive.

In the short run, spending borrowed funds increases the demand for goods and services (including investment goods and services). ${ }^{56}$ During the repayment stage, however, the reverse takes place. One is reminded of the movements of tides during high tide and low tide. Because at some point borrowers need to repay the funds they borrowed and spent (low tide), they will have to reduce their spending in order to repay loans. Moreover, because they need to repay loans with interest, they will need to reduce their spending in the repayment stage by more than the amount by which they increased their spending during the initial stage of borrowing and spending. In other words, the "low tide" is more pronounced than the "high tide". This means that over the entire cycle of borrowing, spending and repayment, the total effect on demand (and therefore economic activity) will be negative.

To put it differently, because repayments of loans always exceed the loans by an amount equal to the total of interest payments made, interest-based financing over the longer term invariably withdraws more money from the real economy in the form of loan repayments than it injects into it in the form of the expenditure of borrowed funds. This means that over the cycle of borrowing, spending and repayment, leakages from the circular flow of income exceed injections.

Any excess of leakages from the circular flow of income over injections will - if standard economic theory holds true - result in a contraction of the economy, other factors remaining constant. Because leakages from the circular flow in the form of loan repayments exceed injections in the form of loans, interest-based lending is more likely to impede economic growth than support it, as is commonly believed. ${ }^{57}$

Any reduction of expenditure by consumers and businesses will slow down growth and increase unemployment. Thus, over the longer term, interest-based financing will result in additional unemployment and a reduction of economic growth (GDP). In addition to the inflation caused by riba $\bar{a}$-based financing discussed in the previous section, this means that over the longer term ribā-based financing causes unemployment, reduced economic growth and inflation, all at the same time. In other words, it causes stagflation. Stagflation or the co-existence of high levels of unemployment and inflation is a relatively recent phenomenon. It became prominent at a time of large increases in spending on credit. ${ }^{58}$

In this way, interest-based financing produces effects directly contrary to the primary objectives of sound economic management as measured by all three major 
economic indicators. Thus, while interest-based lending may increase spending and growth in the short run, it does so by decreasing it in the long run. Because of the need to repay loans with interest, the decrease in future will be greater than the increase in the present. Thus, it is clear that interest-based lending does not create new demand; it merely transfers future demand into the present.

The funds repaid to the financial institutions will remain there unless qualified borrowers - those that can post acceptable collateral - can be found. In the absence of qualified borrowers, any funds held by financial institutions are likely to remain there rather than be put to productive use. Thus, to the extent that insistence on collateral traps liquidity within the system, interest-based financial institutions in fact impede rather than foster economic growth.

Savings lying idle within the financial system constitute a waste that has a negative impact on economic activity. Financial institutions who can no longer find qualified lenders (those having acceptable collateral) within the countries they operate turn to lending abroad, once again only to borrowers who can post acceptable collateral. Lending abroad constitutes an additional leakage of funds from the circular flow, and therefore signals additional reduction of growth in the domestic economy.

\section{Ribā and the 'Rationing of Capital'}

It is commonly asserted - in standard economics textbooks for example - that making funds available for investment at predetermined (and sometime fixed) cost (interest) helps to allocate capital more efficiently by "rationing" it to the most efficient businesses. ${ }^{59}$ Ensuring that capital is allocated efficiently comes about by lending it only to businesses profitable enough to pay the rates of interest demanded by capital providers. This effectively disqualifies all less profitable (efficient) businesses from obtaining loans, as they do not earn profits sufficiently high to afford the payments of interest on loans demanded by financial institutions. On the surface, the argument appears to carry weight. Allocating capital to a business able to repay a loan means that only very efficient (profitable) businesses and those able to post strong collateral will receive loan financing.

Ribā-based financing reduces macroeconomic efficiency by reducing the total amount of investment. This takes place because financing by means of interestbased loans reduces the marginal efficiency of capital. More precisely, interest-based financing reduces the marginal efficiency of capital by the rate of interest that a firm needs to pay for the use of loan capital. If the marginal efficiency of capital of a firm is $15 \%$ on a given amount of capital before borrowing at interest, and the cost of funds is $8 \%$, then the need to pay $8 \%$ interest for the use of borrowed capital effectively reduces the marginal efficiency of capital from $15 \%$ to $7 \%(15-8=7)$. 
Expressed differently, a firm will add additional units of capital to the production process as long as the marginal efficiency of capital (additional net profit) is greater than its marginal cost (interest that has to be paid for the use of additional capital). When the marginal efficiency of capital (rate of profit) becomes equal to its marginal cost (rate of interest), any further addition of capital will add more to cost than to profit, thereby reducing overall net profit.

This means that a business that finances investment by borrowing will stop adding capital as soon as the addition to profit (rate of profit) becomes equal to the addition to cost (rate of interest). But a firm that finances investment by issuing shares or profit and loss sharing șukuk need not stop adding capital whenever its rate of profit falls below the interest rate. This means that firms that finance their investments by equity capital or participatory șuku $k$ will invest more, other factors being constant, than firms that finance their investment by loan capital. ${ }^{60}$ This will increase overall investment and therefore also the quantity of resources utilised. In other words, financing by way of profit and loss sharing will allocate resources more efficiently, than financing by way of ribā-based lending.

Financing by way of $r i b \bar{a}$-based lending reduces efficiency in the macroeconomic sense in another way. The minimum rates of interest demanded by banks effectively disqualify all enterprises unable to make sufficient profits to pay at least the minimum rates of interest demanded by financial institutions. As in a competitive environment it is only natural that profits margins are low, this can only mean that a large number of businesses - perhaps only marginally profitable but still profitable - will not qualify for loan financing.

In other words, because lenders will only lend to businesses able to pay the rates demanded, all businesses that earn profits lower than what is required to service and repay loans will be excluded. This may include potentially a very large number of profitable businesses, in particular the small and medium sized businesses or (SMEs). Withholding capital from profitable businesses, even if only marginally profitable, cannot but hinder overall investment. This means lower economic growth and employment, both of which signify, in different ways, lower macroeconomic efficiency.

Moreover, many marginally profitable businesses such as the SMEs operate under highly competitive conditions. For this reason they are also more efficient than businesses that operate under less competitive conditions. This means that rib $\bar{a}-$ based lending, by requiring profit margins to exceed interest rates, may in many cases withhold financing from the most efficient businesses, businesses that most qualify to receive financing.

It is widely acknowledged that the vast majority of employment is created by the small and medium enterprises. Thus under interest-based system of financing, the 
sector providing the greatest number of jobs will be deprived of financing. This in itself will significantly reduce the efficiency in the use of resources, including human resources, by failing to support investment by the SMEs.

Another form of inefficiency arises out of the fact that financial institutions lend on the basis of the borrower's ability to post acceptable collateral, rather than on the basis of the commercial viability and the long-term prospects of success of a given business proposal. This explains why financial institutions tend to lend mainly to large and well-established companies, in particular to monopolies and oligopolies, and only rarely and in limited amounts to small and medium enterprises (SMEs).

Wealth, however, needs to circulate among all segments of society, not only among the wealthy. ${ }^{61}$ Monopolies and oligopolies may well earn the highest profits. But monopolies and oligopolies are also the most inefficient businesses. By lending to monopolies and oligopolies in preference to SMEs, financial institutions, contrary to popular perception, in fact support the most inefficient businesses. A distorted system of financing of this nature can hardly fail to weaken the overall competitiveness of any nation that practices it, and with competitiveness, also the efficiency with which its resources will be allocated. Because financial institutions will only lend to businesses that can post sufficient collateral, interest-based lending in effect provides financing to businesses that need it the least. ${ }^{62}$

\section{Ribā and Social Justice}

Interest-based financing introduces another anomaly in the form of inequality of opportunity. Interest-based financing puts bona fide entrepreneurs at a disadvantage in relation to lenders. Interest-based financing favours lenders (the wealthy) over entrepreneurs (those that wish to become wealthy) in several ways. This favouritism is ensured by the income and capital guarantees that lenders are legally allowed to extract from borrowers. With income and capital guarantees, lenders no longer have to compete with the rest of society. They are effectively guaranteed an income, and insulated from market discipline or the need to compete.

Anyone guaranteed an income has little incentive to strive to become socially useful or productive. Interest-based financing thus produces a moral hazard by providing lenders with an incentive, in the form of interest income, to become or remain unproductive. All lenders need to do is to lend capital at interest and do so on a secured basis, and then simply live off their earnings of interest. The capital they lend need not even be their own; it can belong to other people, as indeed it does in most cases. On account of income and capital guarantees, unlike other members of society, creditors are protected from risk of losses. The differences between lenders and entrepreneurs have become blurred to such an extent that hardly anyone notices them, let alone calls for clearly differentiating between investment and lending. 
Apart from the unfairness of permitting a class of unproductive persons (shareholders of institutions earning riba $)$ to live off the labour of others, earning guaranteed income (interest) is problematic for other reasons. Guaranteeing income to one group (lenders) but not to others (entrepreneurs) undermines the principle of the equality of opportunity and fair play. Entrepreneurs who face risk in their efforts to earn profits do not have the same opportunities as lenders, whose gains (interest income) as well as capital (loans) are both guaranteed.

The institutionalisation of the bias in favour of creditors is also evidenced by the fact that from the point of view of taxation, interest payments can be treated as expenses by all businesses that finance their investments by borrowing. This means that businesses can reduce their taxes by deducting interest expenses from their taxable income. This is not the case, however, with businesses that finance their investments by raising capital on a profit and loss sharing basis, without borrowing. Such companies need to pay taxes on all profits they pay to shareholders in the form of dividends.

When shareholders receive their dividends, they have to pay taxes on the same profits again. In other words, unlike earnings of interest, profits are subject to double taxation, at both company level and the level of the individual shareholder. Interest income, by contrast, is taxed only once, as personal income. This provides an incentive to businesses to raise capital by borrowing rather than by issuing profit and loss sharing securities such as shares or șukuk. This has the effect of undermining the real sector by privileging the financial sector. The bias in favour of interest-based lending in particular permeates the common law system, known for its creditor friendly nature. This means that in the case of disputes, creditors are generally favoured over borrowers by the law.

In part due to the uneven level playing field favouring lending over entrepreneurship, substantial inequalities of wealth between the haves and the have-nots have arisen. It is not uncommon to see pockets of poverty and homelessness even in the most advanced industrial nations, to say nothing of the developing world. ${ }^{63}$ Balanced economic development remains elusive.

Lending at interest has contributed to these inequalities by widening the gap between the rich and the poor. ${ }^{64}$ It does this by ensuring that over the long term the total amount of money (principal and interest) repaid to lenders is invariably greater than the total amount (principal only) loaned in the first place. ${ }^{65}$

Ensuring that the amounts repaid exceed the amounts lent is accomplished by means of income and capital guarantees. The income guarantee is provided by debtors in the form of a commitment (promise) to make fixed loan repayments to creditors on dates and in amounts determined by the creditors in advance.

Capital guarantees are provided by borrowers by posting collateral. Collateral is an asset at least equal to or greater in value than the amount of the loan that the 
creditor can claim from the borrower in the event that the borrower is unable to repay the loan. The requirement for borrowers to post collateral means that even if a business financed by a creditor goes bankrupt, the creditor is able to recover his capital without any loss. Thus, there is little risk to the creditor that he may lose his capital. This creates a major moral hazard to the lender in that he may lend money to potentially unprofitable enterprises, as his capital is guaranteed. This explains why significant overinvestment has taken place utilising rib $\bar{a}$-based financing, resulting in enormous surpluses of property, thus evidencing a massive waste of resources: macroeconomic inefficiency.

Income and capital guarantees ensure that creditors, unlike entrepreneurs, can suffer no loss and are in addition guaranteed income in the form of periodic payments. In other words, the income and capital guarantees ensure that the net flows of capital (in the form of interest payments) over the longer term move in one direction, from borrowers (the needy) to creditors (the wealthy). Thus, over the longer term, wealth is gradually transferred from borrowers to creditors in the form of interest payments.

Yet the community as a whole does not benefit from a progressive concentration of wealth in the hands of the few. It is not in the public interest (mașlahah) to have such a gap. The concentration of wealth in fewer and fewer hands imposes various costs on society. It causes inefficiency in two ways: the wealthy are able to command a surplus of goods and services. Their wealth in many cases is so large that they cannot possibly hope to consume any such surpluses. The poor, on the other hand, on account of their poverty, often experience regular shortages of (even essential) goods and services.

Wealthy parties (creditors) are unlikely to spend much of any additional wealth acquired by way of consumption, by far the single largest component of aggregate demand. A single person can at most eat one meal, wear one set of clothes, occupy one house, or drive only one automobile at any one time. The demand for these goods is therefore not likely to increase dramatically as a result of an increase in the wealth of those who are already wealthy.

One may note in addition that the limited ability of the wealthy to spend their wealth - and thus contribute to aggregate demand in a significant way - constitutes a compelling argument for utilising development models that seek to distribute wealth widely rather than narrowly among the population. This would increase the disposable of each person according to his ability or effort. A higher disposable income among the general population will contribute significantly more to GDP by stimulating aggregate demand than making a few persons wealthy, in the expectation that the trickle-down effect will do the rest. As this paper has attempted to show, rib $\bar{a}-$ based financing on the contrary ensures a "trickle up" rather than a "trickle down". This is accomplished by way of income and capital guarantees, which have the effect of concentrating wealth in the hands of the few, thereby significantly constraining economic growth and development. 
As no substantial increase in aggregate demand can be expected from an increase in the wealth of those already wealthy, no significant increase in production (GDP) is likely to take place either, to cater to any increase in demand for goods and services resulting from an increase in new wealth. Aggregate demand remains depressed because the majority of the population benefit little from the gains in wealth that largely flow to the wealthy.

What is more, lenders are generally risk-averse and therefore rarely invest in the real economy. As a result, another major component of aggregate demand investment - is unlikely to rise significantly as a result of an increase in the wealth of those already wealthy. Sluggish consumption and investment will hamper overall production (GDP) and therewith constrain the efficiency with which resources can be utilised. Moreover, a substantial gap between the rich and poor can be socially divisive. Thus, concentration of wealth in progressively smaller number of hands does not serve the public interest (mașlaḥah). On the contrary, it undermines it.

\section{Conclusions and Recommendations}

The major shortcoming of interest-based financing is that it displaces to a substantial degree the dominant incentive for parties with surplus capital (savers) to maximise efficiency in entrepreneurial activity - income in the form of profit - by a weaker incentive: income in the form of interest. These two incentives operate in different ways, which have different implications on the efficiency with which resources will be allocated.

The main difference between the two incentives is that, unlike dividends paid to investors, the amount of interest income paid to creditors does not depend on the efficiency (profitability) of the business receiving financing. This is perhaps the most glaring weakness of interest-based financing.

Because in interest-based lending no link exists between performance (efficiency) and the rewards (in the form of interest payments), lenders have little incentive to make loans to businesses that are likely to earn profits higher than the minimum amounts required to repay loans. Should such businesses make profits higher than those required to repay loans, creditors will still receive only the previously agreed upon sums. Thus, compared to profits, payments of interest provide only a weak incentive to allocate resources efficiently, to channel capital to the most efficient (profitable) businesses.

In comparison to financing on the basis of profit and loss sharing, the quantum of interest earned by creditors is determined before profits, from which payments of interest will have to come, have been earned. In other words, the quantum of interest payments, unlike the quantum of dividends paid to investors, is established in advance and independently of the profitability (efficiency) of the enterprises financed by way of loans. Interest payments to creditors remain constant regardless of fluctuations in profit levels. 
Determining rewards to creditors independently of the performance of the enterprise they finance departs from a basic principle of the free enterprise system, if not also of justice, which is that reward, whether to persons or businesses, needs to be linked to, and indeed depend on, performance. The link between reward and performance provides an incentive to perform, to allocate resources efficiently. Where the link between performance (efficiency) and reward is severed - as the experience of communism has demonstrated - resources are unlikely to be allocated efficiently. A significant amount of waste in the form of persistent surpluses as well as shortages can be expected.

Since interest-based financing hinders rather than promotes the efficient allocation of resources, by reducing the amount of investment and production in any economic system that utilises it, it is recommended that interest-based financing be phased out, and replaced by financing on the basis of profit and loss sharing, on the grounds that interest-based financing, far from serving the public interest (mașlahah), has in fact undermined it by reducing efficiency in the allocation of resources:

- $\quad$ phase out interest-based financing, for example by permitting businesses to sell their products directly to consumers on a deferred basis;

- $\quad$ enable consumers to purchase items on an instalment basis, while ensuring that the credit price is the same as the spot price in order to avoid riba

- $\quad$ promote microfinance with incentives, such as tax advantages;

- $\quad$ amend the law to ensure that payments of interest to creditors can no longer be treated as expenses by firms, thereby enabling them to reduce their taxable income;

- $\quad$ simplify listing requirements and procedures on order to reduce the costs of raising capital by issuing shares;

- avoid incurring debts by utilising financing on the basis of profit and loss sharing;

- review and repeal all existing rules and regulations that serve no purpose other than to limit or eliminate competition in various sectors.

\section{Notes}

1. Iman Sugema, Toni Bakhtiar, and Jaenal Effendi, "Interest vs Profit-Loss Sharing Credit Contract: Efficiency and Welfare Implications," International Research Journal of Finance and Economics (2010), 58-67, available online at http://www.eurojournals.com/irjfe_45_05.pdf (accessed on 24 May 2012).

2. M. Umer Chapra, Islam and Economic Development (Islamabad: International Institute of Islamic Thought and Islamic Research Institute, 1993), 7-8.

3. "Warde Says Ethics Central Tenet to Islamic Finance," The Washington Post, 25 May 2011, 
available online at http://www.washingtonpost.com/business/warde-says-ethics-central-tenet-toislamic-finance/2011/05/25/AGbgPPBH_video.html (accessed online on 29 May 2012) (interview of Ibrahim Warde, with Lisa Murphy on Bloomberg Television's "Fast Forward").

4. Mervyn K. Lewis, "The Cross and the Crescent: Comparing Islamic and Christian Attitudes to Usury,” Iqtisad: The Journal of Islamic Economics 1, no. 1 (April 1999), 20.

5. John R. Presley and John G. Sessions, "Islamic Economics: the Emergence of a New Paradigm," The Economic Journal, 104, no. 424 (May 1994), 584-596, available online at http://www.jstor.org (accessed on 29 May 2012).

6. Shahrukh Rafi Khan, Profit and Loss Sharing: An Islamic Experiment in Finance and Banking (Oxford: Oxford University Press, 1987), 158, also available online at http://www.jstor.org (accessed on 28 May 2012).

7. Hans Visser, Islamic Finance: Principles and Practice (Cheltenham, UK: Edward Elgar, 2009), 144. According to Visser, "the benefits of Islamic finance [...] do not amount to much" (ibid., 137).

8. Ibid., 145 .

9. Ibid.

10. Matthew, 7:3-5.

11. Abdullah Saeed, Islamic Banking and Interest (Leiden E. J. Brill, 1996), 93; see also ibid., 89 and 92.

12. Mahmoud A. El-Gamal, Islamic Finance: Law, Economics, and Practice (Cambridge: Cambridge University Press, 2006), 26.

13. Visser, Islamic Finance, 134

14. "Savings and Souls," The Economist, 4 September 2008, available online at http://www.economist. com/node/12052687 (accessed on 23 May 2012).

15. Alex Hern, "Growing State of Islamic Finance," The New Statesman, 11 April 2012, available online at http://www.newstatesman.com/blogs/markets-and-currency/2012/04/growing-stateislamic-finance (accessed on 29 May 2012).

16. In the United Kingdom, "Adair Turner, the chairman of the Financial Services Authority [...] [described] much of what bankers do as 'socially useless' and called for a tax on financial transactions (the Tobin tax)" (Brian Caplen, "Socially Useful," The New Statesman, 8 January 2010, available online at http://www.newstatesman.com/business/2010/01/banks-financial-taxcity-love, accessed on 29 May 2012).

17. I am referring to the shareholders of financial institutions that earn interest income, not to the employees of such institutions such as clerks, tellers, security personnel and even officers such as bank managers.

18. Campbell R. McConnell and Stanley L. Brue, Economics (New York: McGraw Hill, Inc., 1996, $13^{\text {th }}$ ed.), 590 .

19. In the United States, with a 15 trillion US\$ GDP, using $7.5 \%$ (the average of $5 \%$ and $10 \%$ ) gives 1,125 trillion US\$ paid in interest payments alone.

20. Ann Pettifor, The Coming First World Debt Crisis (New York: Palgrave Macmillan, 2006), 166 and 178

21. Qur'ān 2:275.

22. Mohammad Hashim Kamali, Islamic Commercial Law (Kuala Lumpur: Ilmiah Publishers, 2002), 66-70.

23. Profit and loss sharing (participatory) and interest-based (loan) contracts in addition establish radically different (social) relations among people who utilise these forms of financing. Some of these relations are more in harmony with the world-view of Islam than others.

24. Mabid Ali Al-Jarhi, "Regaining the Ethical Standards of Islamic Finance" (2010), available online at http://www.assaif.org/content/download/8984/49463/file/Regaining\%20the\%20Ethical\%20 
Standards\%20of\%20Islamic\%20Finance.pdf (accessed on 19 May 2012), 15.

25. Ibid., 19.

26. J. M. Keynes, The General Theory of Employment, Interest, and Money (London: Macmillan and Co., Ltd, 1936), 22, quoted in Zahid Bin Zamir, "Why Does Islam Prohibit Interest (Riba)? - The Social, Moral and Economic Rationale," available online at http://www.kantakji.com/fiqh/files/ riba/p213.pdf (accessed on 5 June 2012).

27. Mohammad Nejatullah Siddiqi, "The Wisdom of the Prohibition of Interest," paper presented at the LaRiba annual meeting at Los Angeles CA on 30 March 2002, available online at http://www. siddiqi.com/mns/Interest_Prohibition.html (accessed on 27 May 2012).

28. Susan Smillie and Hilary Osborne, “Q\&A: Islamic Finance,” The Guardian, 13 June 2006, available online at http://www.guardian.co.uk/money/2006/jun/13/accounts.islamicfinance (accessed on 29 May 2012).

29. M. Umer Chapra, Towards a Just Monetary System (Leicester UK: The Islamic Foundation, 1985), 71.

30. Pettifor, The Coming, 173.

31. In a mere three years, the debt of Greece increased from $€ 263$ billion in 2008 to $€ 355$ in 2011, while the GDP declined from $€ 233$ to $€ 218$ in the same period. This means that Greece's debt increased as a proportion of GDP from 113\% in 2008 to 163\% in 2011 (Volkery, "European Union").

32. Siddiqi, "The Wisdom."

33. Umer Chapra, "The Global Financial Crisis: Some Suggestions for Reform of the Global Financial Architecture in the Light of Islamic Finance," Thunderbird International Business Review, Wiley Online Library, 18 August 2011, available online at http://onlinelibrary.wiley.com/doi/10.1002/ tie.20435/abstract (accessed on 24 May 2012).

34. Kenneth Rogoff and Carmen M. Reinhart, This Time is Different: Eight Centuries of Financial Folly (Princeton: Princeton University Press, 2009), 18 and 142.

35. “Abu Dhabi's Sovereign Wealth Fund Ranked World's Largest,” 9 February 2012, accessed online on 24 May 2012; available online at http://www.menafn.com/menafn/1093481730/Abu-Dhabissovereign-wealth-fund-ranked-worlds-largest (accessed on 24 May 2012).

36. Muhammad Saleem, "Islamic Finance Has much to Learn from the West," Financial Times, 19 January 2007, available online at http://www.ft.com/intl/cms/s/0/8678e300-a766-11db-83e40000779e2340.html (accessed on 23 May 2012).

37. "Greek political party leaders must agree to the austerity and reform program designed by the ... European Commission, the European Central Bank and the IMF. Some $€ 3.3$ billion in savings must be secured by the end of 2012. Fifteen-thousand public sector jobs must be slashed, the gross minimum wage cut from $€ 751$ to $€ 586$ and public sector salaries are to be frozen for as long as it takes for unemployment to drop from its current 20.9 percent to 10 percent [...]. Greece's private creditors, which own some $€ 200$ billion in Greek debt, are to relinquish at least 50 percent of their claims. The goal is to ensure that the country's sovereign debt falls to 120 percent of gross domestic product by 2020. Currently, it stands at 163 percent of GDP" (Carsten Volkery, "European Union Keeps Pressure on Athens," Spiegel Online International, 10 February 2012, available online at http://www.spiegel.de/international/europe/insufficient-terity-european-union-keeps-pressure-on athens-a-814464.html (accessed on 27 May 2012).

38. Qur'ān 25:67.

39. Ibid., 7:31.

40. Ibid., 17:26.

41. al-Imam Muhammad Ibn al-Hassan al-Shaybani, The Book of Earning a Livelihood, transl., intro., annot. by Adi Setia (Kuala Lumpur: IBFIM, 2011), 89.

42. The supply of housing, power, water, food, clothing, and health services, education, communication, 
and transportation facilities (roads, highways, ports and airports) constitute some examples.

43. Because an increase in the price level reflects an increase in the costs of production.

44. F. A. Hayek, "The Use of Knowledge in Society," American Economic Review 35, no. 4 (1945), 519-530

45. "Substantial" competition may be said to exist when no single firm is able to affect prices by manipulating output.

46. Waleed A. J. Addas, Methodology of Economics: Secular vs Islamic (Kuala Lumpur: International Islamic University Malaysia Press, 2008), 103.

47. Qur'ān 9:34-35. A saying attributed to the Prophet Muhammad states, "The man who withholds goods is evil. If God lowers prices he is grieved, and if He raises then he is happy" (Bayhaqī), retrieved from the "Sayings of Muhammad" at Ghazi Ahmad, Islam and Muslim Blog, available online at http://islam-n-muslim.blogspot.com/2012/04/hadith-about-hoarding.html (accessed online on 31 May 2012).

48. Qur'ān 20:15, 39:35, 45:22, 46:19.

49. "Faith-Based Finance: The Whys and Wherefores of Islamic Finance," The Economist, 4 September 2008, available online at http://www.economist.com/node/12052679 (accessed on 23 May 2012).

50. Friedrich Hayek, The Road to Serfdom (Chicago University of Chicago Press, 1994).

51. Chapra, Towards, 71.

52. Saeed, Islamic Banking, 76 and 144.

53. Murray N. Rothbard, "The Case for a 100 Percent Gold Dollar," in: Leland Yeager (ed.), In Search of a Monetary Constitution (Cambridge MA: Harvard University Press, 1962), 94-136, available online at http://www.lewrockwell.com/rothbard/rothbard-lib.html (accessed on 28 May 2012).

54. Velocity of money (V) is the average number of times a given unit of currency is used in one year.

55. Kamali, Islamic Commercial Law, 65 and 70-74.

56. This may be good for the economy as long as some unemployment remains. If full employment is reached before the borrowed money is spent, however, any additional increase in demand will cause unnecessary inflation.

57. Kenneth Rogoff, "Nightmare on Kaiserstrasse," Business Economics 46, no. 4 (October 2011), 191-194.

58. This took place for example in the US in the decade of the seventies, when ceilings on credit card interest rates in many states were raised, thus leading to a large increase in spending and general indebtedness.

59. McConnell and Stanley L. Brue, Economics, 585-586.

60. Of course there are other costs associated with equity financing, such as listing costs, fees to investments banks, law firms, etc. These costs can in fact be higher than the costs of issuing bonds (borrowing). Thus, the limit to the marginal efficiency of equity capital is in reality likely to be more than zero, although the total expenses of financing by equity, especially over the longer term, are hardly comparable to the cumulative expenses the firm would have to pay in the form of interest charges.

61. Qur'ān 59:7.

62. Ibrahim Warde, "Islamic Finance," Le Monde Diplomatique: English Edition, September 2001, available online at http://mondediplo.com/2001/09/09islamicbanking (accessed on 24 May 2012).

63. Mohammad Nejatullah Siddiqi, "Faith and Finance: Value Guided Pursuit of Interests," April 2010, available online at http://www.siddiqi.com/mns/ (accessed on 27 May 2012).

64. Asyraf Wajdi Dusuki, "Do Equity-Based Sukuk Structures in Islamic Capital Markets Manifest the Objectives of Shariah?” Journal of Financial Services Marketing Supplement (Special Issue: Islamic Finance: Challenges and Opportunities) 15, no. 3 (December 2010), 203-214.

65. Siddiqi, "The Wisdom." 